are in the decided majority. Our solar system may prove to be an extreme type of system, rather than an average type. Though generously endowed with planets, the sun is the only star known that has no close companion star.

\section{Optical Phenomena in the Atmosphere}

L/CrL. V. S. TAylor, 6 Field Park Coy., R.E., C.M.F., writes: "The discussion on optical phenomena in the atmosphere in Nature of December 9, 1944, brings to mind an occurrence frequently witnessed at Anzio while it was a beachhead. During, and immediately after, intense A.A. fire under conditions of virtually clear sky, with the sun behind the observer, concentrically disposed wave ripple ares could be seen passing away from the barrage zone, in the portion of the sky about $45^{\circ}$ forward of the observer. The acute compression of the atmosphere peripheral to the bursting shells caused the compression zones to be sufficiently altered in refractive index to produce an optically visible phenomenon when refracting undiffused sunlight." This phenomena would seem to be similar to the concentric waves observed by Dr. A. H. Goldie following a bomb burst (Nature, 154, 738 ; 1944).

\section{Post-War Bread in Britain}

Tre Ministry of Food, in collaboration with the Health and other Departments interested, has arranged a conference with the industrial and trade organizations principally concerned with post-war bread. It is hoped that the discussions of the conference will assist the Departments in advising Ministers on post-war flour and bread policy and in particular on any regulations which may have to be made after war-time control ends. The milling and baking industries, the flour importing trade and the co-operative movement have been asked to nominate representatives to the conference; invitations will be addressed to other interests later as may be necessary. The conference will be attended by the Lord Horder (personal adviser to the Minister of Food on medical aspects of food problems), Sir Jack Drummond (scientific adviser to the Ministry of Food), Sir Wilson Jameson (chief medical officer of the Ministry of Health), Dr. Andrew Davidson (chief medical officer for the Department of Health for Scotland) and Sir Edward Mellanby (secretary of the Medical Research Council). In addition, there will be present administrative officers representing the Ministry of Food, the Ministry of Agriculture and Fisheries and the Ministry of Health. Sir Henry French, the permanent secretary of the Ministry of Food, will be the chairman of the conference.

\section{Agricultural Scholarships}

The Ministry of Agriculture and Fisheries invites applications for ten senior scholarships, tenable at university departments of agriculture, or agricultural colleges, for degree or diploma courses in an agricultural subject; or at veterinary colleges for courses in veterinary science; and for six extended junior scholarships (for those who have already held junior awards), and sixty junior scholarships, tenable at farm institutes or similar institutions, for courses not exceeding a year, in agriculture, horticulture, dairying or poultry husbandry. The scholarships are open to the sons and daughters of agricultural workmen or of working bailiffs, smallholders and other rura] workers, and to persons who are themselves bona fide workers in agriculture. The value of the awards is such that neither the recipients nor their parents are normally required to make any contribution towards the cost of the training provided. The usual method of selection is by interview. Full information concerning the scheme and forms of application may be obtained from the Secretary of the Ministry, Block 4, Bickenhall Mansions, Baker Street, London, W.1, or from the offices of County Councils. The latest date for submitting applications is April 30, 1945.

\section{The Night Sky in April}

NEw moon occurs on April 12d. 12h. 29m. U.T., and full moon on April $27 \mathrm{~d}$. $10 \mathrm{~h}$. $33 \mathrm{~m}$. The following conjunctions with the moon take place: April 9d. 19h., Mars $3^{\circ}$ N. ; April 17d. 13h., Saturn $0.1^{\circ}$ N. ; April 23d. 06h., Jupiter $3^{\circ}$ S.; April 26d. 18h., Mercury $6 \cdot 3^{\circ}$ S. Only one occultation of a star brighter than magnitude 6 takes place in April, namely, 8 Leon., which disappears on April 21d. Ih. $29.7 \mathrm{~m}$. Mercury sets at $20 \mathrm{~h}$. $1 \mathrm{~lm}$. at the beginning of April and rises at $4 \mathrm{~h} .10 \mathrm{~m}$. at the end of the month, about 25 minutes before sunrise. The planet is in inferior conjunction on April 13 and is stationary on April 3 and 25. Venus is a conspicuous object in the westerm sky in the early portion of the month, setting at 21h. on April 1. On April 30 the planet rises at $3 \mathrm{~h} .35 \mathrm{~m}$., an hour before sunrise. Venus is in inferior conjunction on April 15. Jupiter is visible throughout most of the night, setting at $5 \mathrm{~h} .13 \mathrm{~m}$. and $3 \mathrm{~h} .14 \mathrm{~m}$. at the beginning and end of the month, respectively. Saturn can be seen in the early portion of the night, setting at $1 \mathrm{~h} .49 \mathrm{~m}$. and just after midnight at the beginning and end of the month, respectively. The Lyrid meteors are active during April 18-22, but moonlight will interfere with the observation of the shower.

\section{Announcements}

WE regret to record the death on March 23 of Sir Napier Shaw, F.R.S., the doyen of British meteorologists, aged ninety-one.

Botanists will be pleased to learn that Mr. E. J. H. Corner, assistant director of the Botanical Gardens, Singapore, who has been in the hands of the Japanese since the fall of Malaya is, according to a cable received from him, "well, happy, working as a botanist".

Dr. Thomas A. JAGgar, the well-known volcanologist, has been awarded the Franklin L. Burr Prize of 1,000 dollars by the National Geographic Society. The Prize, established under a bequest of the late Mary C. Burr of Hartford, Connecticut, provides for cash prizes to members of the Society's expeditions considered to have done especially meritorious work in the field of geographical science. The award was made to Dr. Jaggar for his part in the development of an amphibian mobile boat in 1927, which was used by a National Geographic Society expedition headed by Dr. Jaggar to carry on researches in Alaska in the region of Pavlof Volcano during 1927-28.

A course of twelve lectures in special librarianship has been arranged by the Association of Special Libraries and Information Bureaux, and will be held at the London School of Hygiene and Tropical Medicine, Keppel Street, Gower Street, London, W.C.1, at weekly intervals starting on April 18, at 4.30 p.m. Applications to attend should be sent to the General Secretary, ASLIB, 52 Bloomsbury Street, W.C.l, as soon as possible; the fee is $£ 55 s$. for the course. 